\title{
Dermatologi uten professor
}

\author{
For første gang siden 1851 er Universitetet i Oslo uten professor \\ i hudsykdommer. Bare tre av overlegene ved Rikshospitalets hud- \\ avdeling har doktorgrad. Situasjonen skyldes ikke svak rekruttering \\ av leger til dermatologisk forskning, men at hudleger med akademisk \\ kompetanse slutter.
}

Spesialiteten hud- og veneriske sykdommer var en av de første som ble skilt ut fra «moderspesialiteten» indremedisin. Det første norske professoratet i dermatologi og venerologi ble opprettet i 1851 ved Rikshospitalet i Oslo. Senere ble det etablert hudavdelinger også ved Ullevål sykehus og i Bergen, Trondheim og Tromsø. I 2007 ble hudavdelingene ved Rikshospitalet og Ullevål universitetssykehus slått sammen for aldersgrensen. Alle de fem legene som har tatt doktorgrad de siste ti årene, har sluttet ved avdelingen - fire av dem til fordel for privatpraksis. Studentundervisningen $\mathrm{i}$ hudsykdommer opprettholdes nå med midlertidige ansettelser i bistillinger som førsteamanuensis, mens en professor i bistilling tar seg av undervisningen i seksuelt overførbare sykdommer. Fra sommeren 2009 vil bare tre av avdelingens

\section{«Likegyldighet og mistro i ledelse og blant nøkkelpersonell er svært negativt.»}

og plassert under Medisinsk klinikk ved Rikshospitalet. Noe av begrunnelsen var å styrke dermatologisk forskning.

Moderne dermatologisk behandling er basert på molekylærbiologisk og immunologisk forskning. Bedre innsikt i sykdomspatogenese og nye, potente behandlingsmetoder har de siste tiårene endret klinisk praksis betydelig. Store deler av behandlingen, også av alvorlige og utbredte hudsykdommer, skjer nå poliklinisk.

\section{Leger med doktorgrad forlater sykehus}

Norsk dermatologisk forskning har i mange år stått langt svakere enn i våre nordiske naboland. Hudavdelingene i Trondheim og Tromsø og i noen grad Bergen har i flere år hatt vansker med å fylle sine akademiske stillinger.

I Oslo, derimot, har situasjonen vært bedre. Inntil nylig var tre professorater ved Rikshospitalet, to ved Ullevål og ett ved Olafiaklinikken besatt med kvalifiserte leger. Forskerrekrutteringen har også vært tilfredsstillende - de siste ti årene har fem leger ved eller med tilknytning til avdelingen tatt doktorgrad i et dermatologisk emne. For tiden er seks leger i ulike faser av sitt doktorgradsarbeid.

I løpet av få år er denne situasjonen endret. Fire professorer i Oslo har sagt opp sine stillinger lenge før oppnådd pensjonsalder for å gå over $\mathrm{i}$ annen virksomhet tre av dem til privatpraksis. Én har gått av overleger ha doktorgrad - i tillegg har to underordnede leger doktorgrad.

Dette er en dramatisk situasjon, ikke bare for landets ledende hudavdeling, men for norsk dermatologi som helhet.

\section{Ny personalpolitikk etterlyses}

I de fleste bedrifter har man forstått betydningen av en aktiv personalpolitikk, særlig i tider med sviktende rekruttering og stort frafall av nøkkelpersonell. Det medisinske fakultet i Oslo har igangsatt gode tiltak for å styrke rekrutteringen av unge leger til forskning, bl.a. egen forskerlinje i studiet, men mangler en personalpolitikk som motvirker at leger med doktorgrad slutter.

Det er neppe tilfeldig at så mange leger med doktorgrad slutter ved en avdeling i løpet av så kort tid. Det å være overlege ved et universitetssykehus med bistilling som professor er åpenbart ikke like attraktivt som tidligere, og privat tilleggspraksis for leger i full overlegestilling er kontroversielt. Frafallet kan ikke bare avskrives som et resultat av individuelle valg, vanskelige omstillinger på sykehus og/eller bedre økonomiske vilkår i privatpraksis. De fleste av dem som har sluttet, har gjort det med tungt hjerte; de trives med å forske, veilede og undervise. I en kvalitativ studie blant forskningskompetente hudleger som hadde sagt opp sin sykehusstilling var mangel på autonomi, støtte og ros fra arbeidsgiver like viktige begrunnelser for å slutte som bedre inntektsforhold i privatpraksis (1).
I Bergen er det nylig utlyst en 20-50\% stilling som professor/førsteamanuensis i dermato-venerologi, der det er «aktuelt å vurdere kombinasjonsstilling ved Universitetet og Haukeland Universitetssjukehus, for eksempel $50 \%+50 \%$ eller $20 \%+$ $100 \% »(2)$. Dersom fakultetet i Oslo hadde vært villig til å vurdere liknende pragmatiske ordninger, for eksempel $50 \%$ overlegestilling, kunne Rikshospitalet fortsatt hatt en professor i hudsykdommer. Nå mister avdelingen en forsker med stor arbeidskapasitet, tverrfaglig nettverk, internasjonale kontakter og flere stipendiater under veiledning.

Som følge av omorganiseringer og trange budsjetter må Rikshospitalets hudavdeling innstille seg på færre stillinger, færre senger, kortere liggetid og en strengere henvisningspraksis. Avdelingens oppgaver vil i større grad enn tidligere være knyttet til avansert behandling, «second opinion», forskning og undervisning av studenter og spesialistkandidater. Dette innebærer større krav til spisskompetanse blant legene. Likevel har mange av legene kommet i tvil om oppriktigheten ved fakultetets og klinikkledelsens forsikringer om at avdelingens forskning skal styrkes. For en sykehusavdeling som står foran store utfordringer, er likegyldighet og mistro i ledelse og blant nøkkelpersonell svært negativt.

Norsk akademisk dermatologi er nå inne i en svært kritisk fase - da må man bruke mulighetene og ikke bli handlingslammet av hindringene. Sykehus og fakultet må utvikle en mer gjennomtenkt og tidsriktig strategi for å beholde leger med akademisk kompetanse.

\section{Petter Gjersvik}

petjense@online.no

Observatorie terrasse 7C

0270 Oslo

Oppgitte interessekonflikter: Forfatteren er førsteamanuensis ved Universitetet i Oslo med arbeidssted Hudavdelingen, Rikshospitalet.

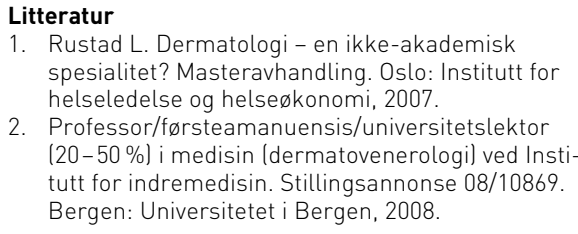

